Article

\title{
Modeling Nature-Based and Cultural Recreation Preferences in Mediterranean Regions as Opportunities for Smart Tourism and Diversification
}

\author{
André Samora-Arvela ${ }^{1}\left(\mathbb{D}\right.$, Jorge Ferreira ${ }^{1}$, Eric Vaz ${ }^{2}$ and Thomas Panagopoulos ${ }^{3, *(1)}$ \\ 1 Interdisciplinary Centre of Social Sciences, Faculty of Social Sciences and Humanities, \\ New University of Lisbon, 1069-061 Lisbon, Portugal; anesamora@gmail.com (A.S.-A.); \\ jr.ferreira@fcsh.unl.pt (J.F.) \\ 2 Laboratory for Geocomputation, Faculty of Arts, Ryerson University, Toronto, ON M5B 1W7, Canada; \\ evaz@ryerson.ca \\ 3 Research Centre for Tourism, Sustainability and Well-being, University of Algarve, Campus de Gambelas, \\ 8005-139 Faro, Portugal \\ * Correspondence: tpanago@ualg.pt; Tel.: +351-289-800-900; Fax: +351-289-818-419
}

Received: 1 December 2019; Accepted: 23 December 2019; Published: 6 January 2020

\begin{abstract}
The tourism and recreational offer of Mediterranean destinations involves, essentially, the promotion of mass tourism, based on the appeal of the sun and beach, and the quality of its coastal assets. Alongside the impacts of climate change, poor tourism diversification represents a threat to the resilience of the territory. Thus, heterogenization of noncoastal tourism products presents an opportunity to strengthen regional resilience to present and future challenges, hence the need to study, comparatively, the complementary preferences of tourists and residents of these regions in order to unveil their willingness to diversify their recreational experience, not only in coastal spaces, but also-and especially-in interior territories with low urban density. Consequently, this strategic option may represent a way of strengthening resilience and sustainability through diversification. In this context, a survey was conducted among 400 beach tourists and 400 residents of a case study—namely, three municipalities of the Algarve region in southern Portugal—in order to analyze their degree of preference for activities besides the sun and beach, such as nature-based and cultural tourism activities, and to probe the enhancement potential of each tourism and recreational activity through the various landscape units considered by experts, stakeholders, and tour operators. The respective degree of preference and enhancement potential were indexed to the area of each landscape unit. Subsequently, respecting the existing recreational structure and constraints, a suitability map for territory enhancement and the implementation of smart tourism practices for each tourism activity and landscape unit is presented. Results show a significant preference for noncoastal outdoor recreational activities.
\end{abstract}

Keywords: sustainable tourism; smart tourism; mobile applications; nature recreation

\section{Introduction}

All Mediterranean regions focus on sun-and-beach tourism as the core of their socioeconomic development. This Mediterranean commonality corresponds to a rarely promoted landscape diversity when compared to the coastal beach sand, the fulcrum of the economic base of these territories. Many sun-and-sea destinations are stagnant, without innovation and without contributing to territorial cohesion, as most of them have low levels of employment and education [1]. This strong focus on beach tourism, coupled with the present and future impacts expected from climate change, especially 
sea-level rise, could weaken regional potential development by reducing the beach bathing area-a major resource for tourist enjoyment in Mediterranean destinations [2].

Due to their landscape diversity, a diversification of alternative products that differentiates Mediterranean destinations-strengthening their attractiveness and regional resilience-can be prolific through the presentation of inimitable products that can only be achieved through the sustainable use of the region's endogenous resources. This can be a way to guarantee the long-term sustainability of tourism destinations [3].

Tourism is seen as a potential factor in mitigating the disparities between rural and urban space [4] when low-density territories are declining in terms of landscape preservation or enhancement. It is essential to find alternative tourism and recreational activities to the standard sun-and-sea tourism in order to sustainably rejuvenate and reinvent Mediterranean destinations. It is paramount, in the first instance, to research the preference of mainstream bathing tourists for other options, such as nature-based and cultural tourism and related recreational activities.

The rejuvenation of destinations by finding and enhancing alternative tourism products should be done through smart tourism policies and practices, assumed as key points for sustainable development [1]. As such, this research presents the territorial model of a case study, namely the municipalities of Silves, Albufeira, and Loulé in the Algarve region, which attracts more than a third of all tourists visiting Portugal.

The aim of this study was to develop a multicriteria evaluation method that diversifies from sun-and-sea coastal tourism by identifying the areas to be enhanced by the public sector and to provide the necessary tools for developing smart tourism, such as websites and geolocation applications focused on tourism promotion, based on effective, efficient, and sustainable management of a wide range of Mediterranean landscape units and products that exist or may emerge in those tourist destinations. The method was based on tourists' and residents' preferences; evaluation of the enhancement potential as considered by experts, stakeholders, and tour operators; and suitability maps for outdoor recreation.

\section{Theoretical Framework}

\subsection{Southwest European Coast Tourism Area Life Cycle}

The evolution of tourist destinations is currently studied through the Tourism Life Cycle Model [5], which is based on five steps: Involvement, exploration, development, consolidation, and stagnation. The first stage, involvement, concerns a tourist's initial interaction with local communities, with an increasing impact on local economies [3]. The second stage, exploration, refers to the intensification of tourism consumption, which can create pressures on the environment and on residents' quality of life.

For Plog [6], in these early stages, tourists try to experience some adventures and some risks, not requiring a high level of institutionalized tourism organization. The development stage, on the other hand, is characterized by an increase in the number of tourists, accompanied by an increase in tourism activities, the emergence of new services (such as organized travel), a marked impact on the daily life of the resident community, and investment by international companies that start operating in developing destinations via accommodation and transportation, among others. Cohen [7] mentions that, at this stage, individual mass tourism gives way to organized mass tourism, that is, explorer tourists are progressively replaced by follower tourists [3].

In this line of development, many destinations face the challenge of the consolidation phase and further stagnation that refers to increasingly anemic tourist activity growth rates and a hegemony of tourist numbers to the detriment of the local population-A characteristic of sun-and-sea destinations, whose main attraction is the seasonal climatic pleasantness. This narrowing attractive base in these destinations often implies an increase in investment in the persistent promotion of sun-and-sea tourism assets that, worldwide, appear to be the least differentiating [3].

After these stages, tourist destinations can follow one of two opposing paths: Stagnation decline, which worsens the deterioration of tourism productivity in presenting tourism products, inherently 
less differentiating, or destination rejuvenation, associated with innovation, product diversification, and its specializing differentiation based on the plural landscape identity of each destination territory. Through this theoretical framework, Romão [3] classifies the various destinations of the southwest coast of Europe according to the current situation stage of their life cycle, such as:

- Exploration: Basilicata, Campania, Lombardy, Molise, Sicilia (Italy), Murcia (Spain);

- Development: Calabria, Lazio, Piedmont, Puglia, Sardegna (Italy), Andalusia (Spain), and Azores (Portugal);

- Stagnation: Abruzzo, Marche, Emilia Romagna, Friuli-Venezia Giulia, Tuscany, Veneto (Italy), Provence-Alps-Cote d'Azur, Corse (France), Canary Islands, Catalonia, Valencian Community, Illes Balears (Spain), Algarve and Madeira (Portugal).

Ricard Butler [8], quoting Russo [9], acknowledges the importance of intervening in tourism management in order to prevent development that exceeds the destination capacity (capacity defined in terms of limits of economic, social, environmental, and physical parameters). If exceeded, the quality of visitor and resident experiences can decline, degrading the inimitable environmental and cultural resources of each destination, and losing visitors, tourist expenditure and, thus, investment capacity in the destination [9]. Agarwal [10] and Baum [11] describe how this tourism area life cycle evolved in regard to the number of stages and shape of the curve, and a comprehensive review of the model applications is contained in Lagiewski [12].

\subsection{Diversification and Differentiation in Tourism}

Among the various tourism product management strategies, Benur and Bramwell [13] point out two key processes: Concentration and diversification. These strategies can be planned at different scales, either by mass intensification or niche creation. The concepts of tourist destination and tourist experience are inextricably linked, as tourists perceive destinations as an integrated experience, derived from a large set of products and services provided in each destination that seeks to meet the motivations and expectations of each tourist [3].

Unlike concentrating on a single product, product diversification is based on offering a diverse set of activities and experiences to attract a wide and flexible multiplicity of tourist segments, which is ultimately the ultimate guarantee of competitiveness, resilience, and sustainability of tourist destinations and, as such, of their supporting territories and local communities [14].

It should be noted that tourism diversification is achieved by encouraging alternative products through their promotion and appreciation. Tourism diversification can only be effective if it leads to product differentiation among the tourist segments it aims to captivate, which is the affirmation of activities and services based on the preserved biophysical and cultural identity of a territory with the goal of ensuring a long-term and sustainable attractiveness, thus generating tourist fidelity, supported not by the low prices' leadership, but by the supply's nonimitable characteristics $[3,14]$. Thereby, the appreciation of destination uniqueness through diversification can be made efficient through innovation, that is, the result of technological evolution of tourism companies, institutions, tourism research and development, and the interactivity between clients and companies through information technologies.

The programming of inimitable resources of each destination into tourism products by synergy between communities and operators is still lacking and latent, as the recognition of their authenticity and uniqueness, while adding value, provides an opportunity for the rejuvenation of stagnant destinations. Only innovation can bring about the promotion of differentiating tourism diversification and thus assist the sustainable management of each destination, strengthening competitiveness by promoting its real authenticity, not its commodification [14]. 


\subsection{Sustainable Tourism, Competitiveness, and Sustainability of Tourist Destinations}

At this point, it is important to examine the concepts, interrelations, and interdependencies of sustainable tourism, competitiveness, and sustainability of tourism destinations. David Weaver [15], in Sustainable Tourism: Theory and Practice, defines sustainable tourism development as tourism that meets the needs of the present without eroding the capacity for future satisfaction, associating it with Budowski's definition [16], namely, tourism that uses and conserves resources without compromising its productive capacity so as to ensure its long-term viability, that is, tourism that minimizes negative impacts and maximizes positive aspects [15].

Sustainable tourism allows for the preservation, enhancement, and promotion of unique and distinctive features that serve as a basis for the creation of differentiating products that, presented in a diversified manner, affirm the competitiveness of each tourism destination. As such, for Buhalis [17], a destination is competitive if it attracts and satisfies potential tourists, as competitiveness is the ability of one destination to achieve greater success than other competing destinations, which derives from leadership of low prices for mass production with a view to minimizing production costs, differentiating products through tourism promotion of something unique, or an integrated strategy to reach various market segments through a combination of cost leadership and product differentiation within a framework of flexible specialization and permanent innovation [18].

Therefore, the determinants of competitiveness are comparative advantage, demand orientation, organization of the tourism industry, and preservation of local natural and cultural specificities [3]. Thus, the sustainability of a tourist destination comes from the adoption of sustainable tourism patterns that imply the respect of carrying capacity of a territory, precisely through environmental preservation, integration of local communities, and economic viability. A sustainable destination is supported not by the degradation or destruction of natural and cultural authenticity through homogenization of destinations, as is recurrent in sun-and-sea locations with their globalized palm tropicalisms, leading to their stagnation, but by the diversification and differentiation of products with the recognition of distinctive characteristics that support the attractiveness of tourism, that is, a rejuvenation strategy that gradually makes destinations sustainable and thus effectively competitive.

Along these lines, an effective and long-term competitive advantage should come from sustainable tourism through the preservation and enhancement of the destination's environmental and cultural differentiating uniqueness. In this sense, Hassan [19] states that destination development and marketing must pursue the following objectives:

- Promoting awareness and understanding among key stakeholders for sustaining the environment during tourism development;

- Promoting equity in development opportunities;

- Maximizing tourist satisfaction;

- Developing and sustaining the quality of life for the local communities and broadening their support through citizen/non-governmental organizations involvement;

- Maintaining balance among economic, social, and environmental needs; defining physical and social carrying capacity of the destination;

- Developing environmental impact assessments for any tourism development;

- Maintaining the local culture and promoting the image of its values, heritage, traditional way of life, and behaviour;

- Enhancing education and training in management for sustainable tourism development.

\subsection{The Innovation and Rejuvenation Opportunity: Smart Tourism}

In this context, it is important to define innovation: "innovation refers to the process of bringing any new, problem solving idea into use. Ideas for reorganizing, cutting cost, putting in new budgetary systems, improving communication or assembling products in teams are also innovations. Innovation is the generation, acceptance and implementation of new ideas, processes, products or services. 
Acceptance and implementation is central to this definition; it involves the capacity to change and adapt" [20]. It can be grounded not only in product and service innovations, which concern the changes considered as new, and process innovations, where Information and Communication Technology (ICT) plays a major role, but also in managerial and management innovations and institutional innovations [21].

Here, it becomes paramount to establish that the concept of smart tourism integrates the potential role of digital technologies in developing collaborative processes between rival service providers at the destination level and in co-creating destinations and experiences through the increasing interaction between producers and consumers, generating benefits from some particular characteristics of tourism services (interoperability, spatiality, and temporality, implying direct interaction between suppliers and consumers, in the same place and at the same time) [1,22]. However, development should not be considered smart if it is not also sustainable. In addition, rural areas may benefit most from the slow tourism opportunities offered by trails for hiking and gravel biking, because slow tourism offers a more meaningful and deliberate way of connecting with the visited region [23].

In this sense, smart tourism, smart destination and smart region concepts derive from the alignment with the concept of a smart city [24]. A city destination or region is smart when "investments in human and social capital and traditional (transport) and modern (ICT) communication infrastructure fuel sustainable economic growth and a high quality of life, with a wise management of natural resources, through participatory governance." Thus, smart tourism adjuvates sustainable spatial planning in destinations/regions through the development of spaces, infrastructure, and services through knowledge-based innovation strategies, supported by the knowledge and information of specific resources of each region, which governance should be done in concert with public participation at the destination level $[25,26]$.

Nowadays, websites, social networks, geolocation, and mobile applications (apps) are the most widely used technology tools in digital marketing, information, and communication, but their potential in Mediterranean tourism is not still fully understood by institutions and enterprises [27]. In this context, major factors have to be considered when designing and presenting an app. According to Lu et al. [28], the acceptance of technology depends on its perceived ease of use and usefulness, the diffusion of innovation by presenting relative advantage over previous ways of performing the same task, the degree to which an innovation is consistent with the values, beliefs, experiences, and needs of the users, visibility to others.

Thereby, it is recognized the need for delineating rural tourism promotion strategies based on the use of mobile technology. Meanwhile, there is high dispersion and disorderly developed digital information and uneven wireless internet infrastructures. Lu et al. [28] suggest a need to establish "centralized tourism databases and appropriate operational systems to collect, store, exchange, and release tourism data; launch smart tourism service platforms (websites, apps, and digital screens) to enhance tourist experience and destination image; and install vending machines and QR code readers in stations, terminals, hotels, restaurants, and tourism sites to facilitate the adoption of mobile technology in tourism process".

\section{Materials and Methods}

\subsection{Study Area}

The study area corresponds to the municipalities of Silves, Albufeira, and Loule (green area of Figure 1), Algarve region, southern Portugal, marked by its Mediterranean climate and permeated by three fundamental landscape units: Interior Mountains (A), Barrocal Midlands (B), and Coastal Landscape (C) [29]. 


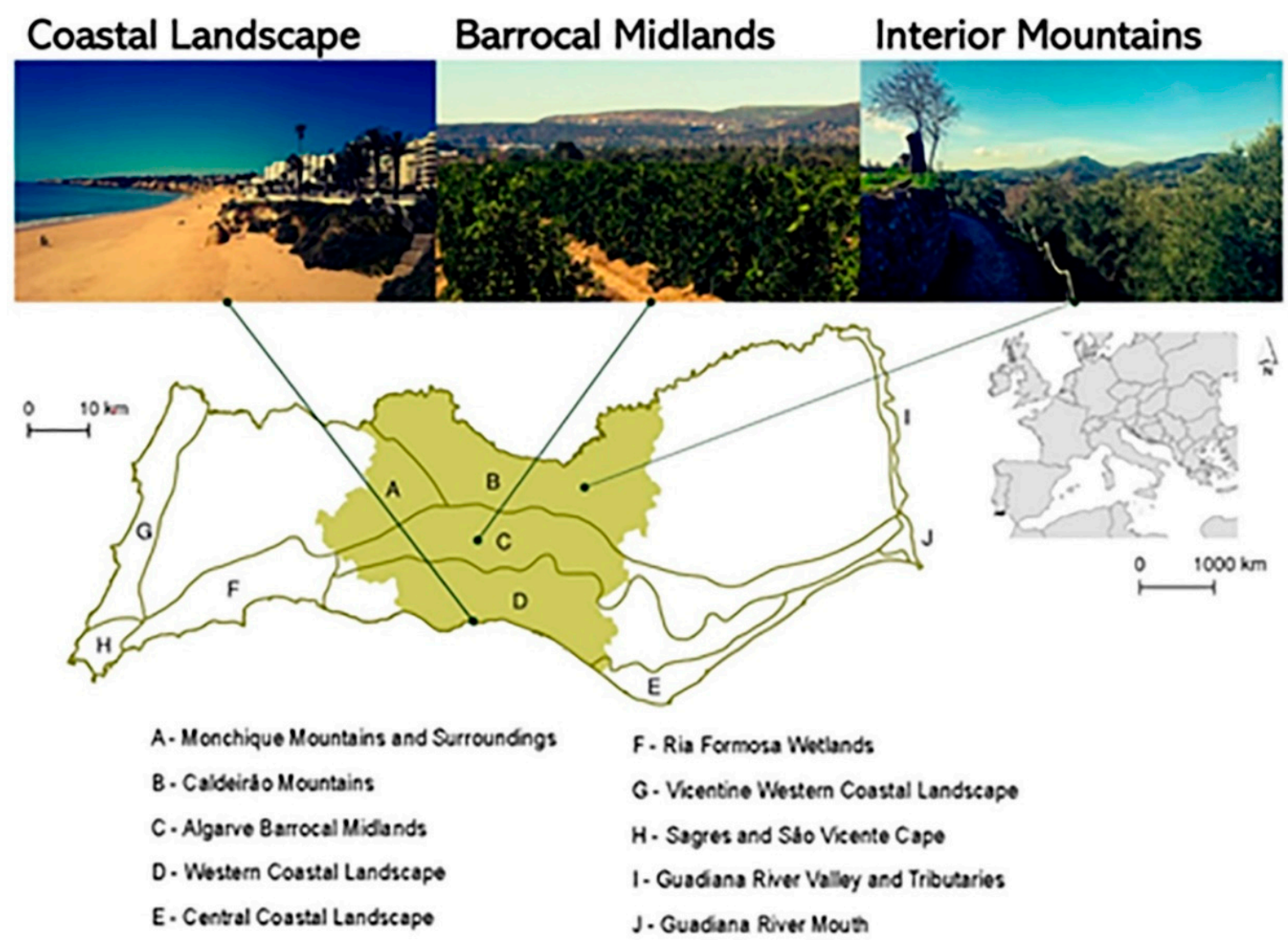

Figure 1. The study area municipalities of Silves, Albufeira, and Loulé within Algarve region, southern Portugal.

The coastline of those municipal territories is consigned to a disorderly urban-tourist occupation, derived from the strict promotion of sun and beach product, whose use is intensive and seasonal. Between the coast and the mountains, the Barrocal Midlands landscape unit is characterized by limestone soils, its agricultural matrix of fig, almond, carob, and olive groves, and the presence of irrigated orange orchards, which is being penetrated by the proliferation of second homes.

It must be acknowledged that agricultural abandonment is relatively transverse to all landscape units of this territory as a consequence of the rural exodus, the commutative transition from agricultural labour to tourism and tertiarization. These problems determine the poor municipal and regional agricultural competitiveness as a result of the fragmented agricultural land structure and the small average size of rustic property, which constituted and constitutes a constraint to agriculture modernization (50\% of farmers in the region have a mean 2 ha farmland) [30].

As such, the integrated landscape management capacity appears to be precarious. The valados walls (dry stone walls to support from terraces and waterfront margins) are not being conserved and are gradually crumbling. Old agricultural plots have been substituted with shrubland, while the Algarve destination simply and simplistically promotes the image of palm tropicalisms imported to its coastline [31]. This situation is even more noticeable in the interior mountainous landscape, marked by the presence of declining cork tree and xerophytic forests, inherent abandonment, desertification and fires.

Without conditions of competitive and sustainable use of its agricultural matrix, one strategy for reinforcing the competitiveness and sustainability of the rural space of these municipalities can and should be the enhancement of their endogenous resources in favour of diversification, differentiation, and innovation in the tourist use of their territories [32]. A diversification aimed at nature-based and cultural tourism activities could be a strategic opportunity, as $60 \%$ of tourists state that Algarve's heritage and cultural offerings are an important attraction in the choice to visit the region [33], and 87\% 
of the tourists who visit the region try to have other experiences beyond the sun and sea. Also, $78 \%$ of tourists point out gastronomy as one of the main attractions [34,35], while the degree of preferential taste for regional Algarve products and sweets is high [36].

It should be noted that these opportunities are crucial in the search for the reinforcement of regional resilience and respective strengthening of the capacity for cultural adaptation of these communities to climate change. It is urgent for these municipalities and others in Mediterranean destinations to adopt a transformative strategy of diversification and promotion of their tourism products through the enhancement potential of diversified endogenous resources, beyond sun and beach, as a means of adaptation, especially with regard to sea level rise, which could reduce the coastal beach area and, consequently, disrupt the socioeconomic base of these regions, which depend so much on it. The attenuation of this dependence through tourism diversification adoption can be a transition towards the reinforcement of the resilience and sustainability of Mediterranean regions.

\subsection{Methods}

The methodology of this article aims at the realization and construction of a territorial model of tourism and recreational enhancement through the following methods.

1. Analysis of questionnaire survey results that assessed the degree of preference of tourists and residents and enhancement potential considered by experts, stakeholders, and tour operators for the promotion of alternative tourism and recreation activities, besides sun and beach, namely nature-based and cultural tourism. The sample size was 400 tourists and 400 residents, and the sample selection was performed using the stratified random sampling method of number of guests in tourist accommodation establishments by municipality in 2015, country of usual residence [37], and number of resident individuals living in the study area [38]. Tourists and residents were surveyed in 2017. Subsequently, the enhancement potential of each tourism and recreational activity was studied through a survey of experts, stakeholders, and tour operators, which, in proportion to the degree of preference of tourists and residents, allowed for assessment of the total potential for enhancement of each activity in each landscape unit.

The preference degree of taste was determined using the numerical scale 1-I don't like it; 2 -I like it a little; 3-I like it relatively; 4-I like it reasonably; 5-I like it; 6-I like it a lot; 0-Does not know/does not answer. The enhancement potential was studied using the following scale: 1 -Not to enhance; 2-To enhance a little; 3-To enhance relatively; 4-To enhance reasonably; 5-To enhance; 6-To enhance a lot; 0 -Does not know/does not answer.

2. Investigation into the existing territorial structure of recreational activities most appreciated in preference and identified as having the greatest potential for enhancement. Digitalization of this information and spatialization in geographic information system maps.

3. Building a suitability map of total enhancement potential of each recreation activity assessed in each landscape unit through the multicriteria evaluation of preference degree of tourists and residents and enhancement potential considered by experts, stakeholders, and tour operators, the distance from existing recreational structures and the zoning of spatial planning policies: Suitability and factors for multicriteria evaluation $[39,40]$.

\section{Results}

Given the mean degree of preference of tourists and residents, and the mean enhancement potential considered by experts, stakeholders, and tour operators for each tourism and recreational activity within the Interior Mountains, it is noted that some are at a level higher than 5 (I like it/To enhance). Walks, orienteering, and fitness circuits being the preferred activity (5.53), followed by health and wellness (5.36), rural accommodation (5.27), gastronomy and wines (5.11), and landscape touring and picnics (5.09), represent the main activities to be enhanced within the Interior Mountains landscape (Table 1). The exceptions with the lowest scores were golf (3.21) and hunting (3.12). 
Table 1. Mean degree of tourists' and residents' preference and enhancement potential considered by experts, stakeholders, and tour operators for each activity within the Interior Mountains.

\begin{tabular}{cccccccccc}
\hline Interior Mountain Area & A & B & C & D & E & F & G & H & Total \\
\hline Walks, orienteering and keep-fit circuits & 4.85 & 5.51 & 4.95 & 5.27 & 6.00 & 6.00 & 5.80 & 5.00 & 5.53 \\
Cycling & 4.27 & 5.51 & 4.22 & 5.27 & 4.33 & 5.71 & 5.13 & 5.00 & 4.84 \\
Mountain biking & 3.10 & 5.51 & 3.51 & 5.27 & 4.33 & 5.57 & 5.20 & 5.00 & 4.54 \\
Birdwatching & 2.25 & 5.51 & 3.10 & 5.27 & 6.00 & 5.86 & 5.50 & 5.00 & 4.79 \\
Golf & 2.43 & 5.51 & 2.61 & 5.27 & 1.33 & 4.00 & 4.00 & 5.00 & 3.21 \\
Bathing, canoeing and fishing & 4.26 & 5.51 & 4.10 & 5.27 & 4.67 & 4.71 & 4.40 & 5.00 & 4.58 \\
Climbing, abseiling and zip-lining & 3.12 & 5.51 & 3.12 & 5.27 & 4.67 & 5.29 & 3.60 & 5.00 & 4.26 \\
Geocaching & 1.90 & 5.51 & 2.52 & 5.27 & 5.33 & 5.00 & 4.57 & 5.00 & 4.20 \\
Hunting & 1.60 & 5.51 & 2.06 & 5.27 & 3.33 & 3.71 & 2.47 & 5.00 & 3.12 \\
Horse riding & 2.74 & 5.51 & 3.15 & 5.27 & 4.67 & 5.00 & 4.00 & 5.00 & 4.21 \\
Cong & 3.77 & 5.51 & 4.86 & 5.27 & 3.00 & 5.57 & 4.80 & 5.00 & 4.52 \\
Other outdoor activities in sports centre & 4.78 & 5.51 & 4.86 & 5.27 & 5.33 & 5.86 & 5.33 & 5.00 & 5.27 \\
Camping & 3.69 & 5.51 & 4.28 & 5.27 & 3.67 & 5.29 & 4.00 & 5.00 & 4.37 \\
Campervanning & 3.34 & 5.51 & 3.71 & 5.27 & 3.67 & 5.57 & 4.07 & 5.00 & 4.30 \\
Health and wellness & 3.20 & 5.51 & 3.82 & 5.27 & 4.67 & 5.71 & 4.21 & 5.00 & 4.55 \\
Temporary integration in eco-farms & 4.89 & 5.51 & 5.21 & 5.27 & 5.67 & 5.86 & 5.00 & 5.00 & 5.36 \\
Gastronomy and wines & 4.72 & 5.51 & 4.98 & 5.27 & 4.33 & 5.71 & 5.73 & 5.00 & 5.11 \\
Touring architectural and archaeological & 4.40 & 5.51 & 4.46 & 5.27 & 5.33 & 5.86 & 5.67 & 5.00 & 5.21 \\
Landscape touring and picnics & 4.63 & 5.51 & 4.50 & 5.27 & 5.00 & 5.71 & 5.27 & 5.00 & 5.09 \\
Outdoor fairs and markets & 4.61 & 5.51 & 4.81 & 5.27 & 4.00 & 5.00 & 5.00 & 5.00 & 4.75 \\
Outdoor shows and performances & 4.63 & 5.51 & 5.18 & 5.27 & 3.50 & 5.29 & 5.13 & 5.00 & 4.79 \\
Outdoor religious processions & 2.54 & 5.51 & 3.78 & 5.27 & 3.33 & 5.14 & 4.13 & 5.00 & 4.05
\end{tabular}

A: $15 \% *$ Mean of tourists' preference for each recreation activity $(\mathrm{N}=400) ; \mathrm{B}: 5 \%{ }^{*}$ Mean of tourists' preference for each landscape unit $(\mathrm{N}=400)$; $\mathrm{C}: 15 \% *$ Mean of residents' preference for each recreation activity $(\mathrm{N}=400)$; D: $5 \%{ }^{*}$ Mean of residents' preference for each landscape unit ( $\left.N=400\right)$; E: 20\% * Mean of enhancement potential considered by experts for each recreation activity and landscape unit $(\mathrm{N}=3) ; \mathrm{F}: 20 \%{ }^{*}$ Mean of enhancement potential considered by stakeholders for each recreation activity and landscape unit (N = 7); G: $15 \%$ * Mean of enhancement potential considered by tour operators for each recreation activity $(\mathrm{N}=15) ; \mathrm{H}: 5 \%$ * Mean of enhancement potential considered by tour operators for each landscape unit $(\mathrm{N}=15)$.

Within the Barrocal Midlands, some activities also exceeded level 5 for surveyed tourists, residents, experts, stakeholders, and tour operators. Rural accommodation (5.42), walks, orienteering, and keep-fit circuits were also the most appreciated and recognized here (5.41). Gastronomy and wines (5.26), touring architectural and archaeological sites (5.16), health and wellness (5.04), and landscape touring and picnics (5.04) were the most preferred and suitable for enhancement in the Barrocal Midlands landscape. The exception was also reiterated for golf (3.36) and hunting (2.87) (Table 2). 
Table 2. Mean degree of tourists' and residents' preference and enhancement potential considered by experts, stakeholders, and tour operators for each activity within the Barrocal Midlands.

\begin{tabular}{cccccccccc}
\hline Barrocal Midlands & A & B & C & D & E & F & G & H & Total \\
\hline Walks, orienteering and keep-fit circuits & 4.85 & 5.30 & 4.95 & 5.26 & 5.33 & 6.00 & 5.80 & 5.53 & 5.41 \\
Cycling & 4.27 & 5.30 & 4.22 & 5.26 & 4.67 & 5.71 & 5.13 & 5.53 & 4.92 \\
Mountain biking & 3.10 & 5.30 & 3.51 & 5.26 & 5.00 & 5.57 & 5.20 & 5.53 & 4.69 \\
Birdwatching & 2.25 & 5.30 & 3.10 & 5.26 & 5.00 & 5.86 & 5.50 & 5.53 & 4.60 \\
Golf & 2.43 & 5.30 & 2.61 & 5.26 & 2.00 & 4.00 & 4.00 & 5.53 & 3.36 \\
Bathing, canoeing and fishing & 4.26 & 5.30 & 4.10 & 5.26 & 4.33 & 4.71 & 4.40 & 5.53 & 4.53 \\
Climbing, abseiling and zip-lining & 3.12 & 5.30 & 3.12 & 5.26 & 3.33 & 5.29 & 3.60 & 5.53 & 4.00 \\
Geocaching & 1.90 & 5.30 & 2.52 & 5.26 & 5.00 & 5.00 & 4.57 & 5.53 & 4.15 \\
Hunting & 1.60 & 5.30 & 2.06 & 5.26 & 2.00 & 3.71 & 2.47 & 5.53 & 2.87 \\
Horse riding & 2.74 & 5.30 & 3.15 & 5.26 & 4.33 & 5.00 & 4.00 & 5.53 & 4.15 \\
Cong & 3.77 & 5.30 & 4.86 & 5.26 & 3.67 & 5.57 & 4.80 & 5.53 & 4.67 \\
Cther outdoor activities in sports centre & 4.78 & 5.30 & 4.86 & 5.26 & 6.00 & 5.86 & 5.33 & 5.53 & 5.42 \\
Camping & 3.69 & 5.30 & 4.28 & 5.26 & 5.00 & 5.29 & 4.00 & 5.53 & 4.66 \\
Campervanning & 3.34 & 5.30 & 3.71 & 5.26 & 3.67 & 5.57 & 4.07 & 5.53 & 4.32 \\
Temporary integration in eco-farms & 3.20 & 5.30 & 3.82 & 5.26 & 4.33 & 5.71 & 4.21 & 5.53 & 4.50 \\
Health and wellness & 4.89 & 5.30 & 5.21 & 5.26 & 4.00 & 5.86 & 5.00 & 5.53 & 5.04 \\
Gastronomy and wines & 4.72 & 5.30 & 4.98 & 5.26 & 5.00 & 5.71 & 5.73 & 5.53 & 5.26 \\
Touring architectural and archaeological & 4.40 & 5.30 & 4.46 & 5.26 & 5.00 & 5.86 & 5.67 & 5.53 & 5.16 \\
Landscape touring and picnics & 4.63 & 5.30 & 4.50 & 5.26 & 4.67 & 5.71 & 5.27 & 5.53 & 5.04 \\
Outdoor fairs and markets & 4.61 & 5.30 & 4.81 & 5.26 & 4.00 & 5.00 & 5.00 & 5.53 & 4.77 \\
Outdoor shows and performances & 4.63 & 5.30 & 5.18 & 5.26 & 4.00 & 5.29 & 5.13 & 5.53 & 4.90 \\
Outdoor religious processions & 2.54 & 5.30 & 3.78 & 5.26 & 3.33 & 5.14 & 4.13 & 5.53 & 4.07
\end{tabular}

A: $15 \%$ * Mean of tourists' preference for each recreation activity $(\mathrm{N}=400) ; \mathrm{B}: 5 \%$ * Mean of tourists' preference for each landscape unit $(\mathrm{N}=400)$; $C$ : $15 \%$ * Mean of residents' preference for each recreation activity $(\mathrm{N}=400)$; D: $5 \% *$ Mean of residents' preference for each landscape unit ( $N=400) ; \mathrm{E}: 20 \%$ * Mean of enhancement potential considered by experts for each recreation activity and landscape unit $(\mathrm{N}=3) ; \mathrm{F}: 20 \%$ * Mean of enhancement potential considered by stakeholders for each recreation activity and landscape unit (N = 7); G: $15 \%$ * Mean of enhancement potential considered by tour operators for each recreation activity $(\mathrm{N}=15) ; \mathrm{H}: 5 \%$ * Mean of enhancement potential considered by tour operators for each landscape unit $(\mathrm{N}=15)$.

For the Coastal Landscape, walks, orienteering, and keep-fit circuits were still the most preferred activity and the one with the most potential of enhancement for this landscape (5.23), along with health and wellness (5.20), gastronomy and wines (5.15), outdoor shows and performances (5.06), and touring architectural and archaeological sites. Exception were geocaching (3.84), outdoor religious processions (3.82), climbing, abseiling and zip-lining (3.69), golf (3.38), and hunting (2.75) (Table 3).

In view of the above, there may be a redirection of tourism promotion in the region, which should favour activities beyond the sun-and-sea product, especially the following: Walking in trails and boardwalks, hiking, orienteering, and keep-fit circuits; cycling, gravel biking; birdwatching; bathing, canoeing and fishing in rivers or lakes; horse riding; other outdoor activities in sports centres (soccer, basketball, tennis, etc.); rural accommodation; camping; campervanning; temporary integration in ecovillages, ecocommunities or ecofarms; health and wellness; gastronomy and wines; touring architectural and archaeological heritage, and museums; landscape touring and picnics, and outdoor fairs and markets.

Regarding the existing recreational structure, the research outcomes have identified the major paths, trails, and suitable spaces for the various recreational activities studied, through the surveys, in order of considered preference and enhancement potential. An example of this is the pre-existing paths for walks, orienteering, and keep-fit circuits (Figure 2). These layers can and should be used in digital marketing of Algarve destinations through the delineation of geolocation algorithm app for the tourism brand Algarve, characterized by integration of these existing layers and by the app's acceptance, diffusion, and social outcomes. 
Table 3. Mean degree of tourists' and residents' preference and enhancement potential considered by experts, stakeholders, and tour operators for each activity within the Coastal Landscape.

\begin{tabular}{|c|c|c|c|c|c|c|c|c|c|}
\hline Barrocal Midlands & A & B & $\mathrm{C}$ & $\mathbf{D}$ & $\mathbf{E}$ & $\mathbf{F}$ & G & $\mathbf{H}$ & Total \\
\hline Walks, orienteering and keep-fit circuits & 4.85 & 5.30 & 4.95 & 5.26 & 5.33 & 6.00 & 5.80 & 5.53 & 5.41 \\
\hline Cycling & 4.27 & 5.30 & 4.22 & 5.26 & 4.67 & 5.71 & 5.13 & 5.53 & 4.92 \\
\hline Mountain biking & 3.10 & 5.30 & 3.51 & 5.26 & 5.00 & 5.57 & 5.20 & 5.53 & 4.69 \\
\hline Birdwatching & 2.25 & 5.30 & 3.10 & 5.26 & 5.00 & 5.86 & 5.50 & 5.53 & 4.60 \\
\hline Golf & 2.43 & 5.30 & 2.61 & 5.26 & 2.00 & 4.00 & 4.00 & 5.53 & 3.36 \\
\hline Bathing, canoeing and fishing & 4.26 & 5.30 & 4.10 & 5.26 & 4.33 & 4.71 & 4.40 & 5.53 & 4.53 \\
\hline Climbing, abseiling and zip-lining & 3.12 & 5.30 & 3.12 & 5.26 & 3.33 & 5.29 & 3.60 & 5.53 & 4.00 \\
\hline Geocaching & 1.90 & 5.30 & 2.52 & 5.26 & 5.00 & 5.00 & 4.57 & 5.53 & 4.15 \\
\hline Hunting & 1.60 & 5.30 & 2.06 & 5.26 & 2.00 & 3.71 & 2.47 & 5.53 & 2.87 \\
\hline Horse riding & 2.74 & 5.30 & 3.15 & 5.26 & 4.33 & 5.00 & 4.00 & 5.53 & 4.15 \\
\hline Other outdoor activities in sports centre & 3.77 & 5.30 & 4.86 & 5.26 & 3.67 & 5.57 & 4.80 & 5.53 & 4.67 \\
\hline Rural accommodation & 4.78 & 5.30 & 4.86 & 5.26 & 6.00 & 5.86 & 5.33 & 5.53 & 5.42 \\
\hline Camping & 3.69 & 5.30 & 4.28 & 5.26 & 5.00 & 5.29 & 4.00 & 5.53 & 4.66 \\
\hline Campervanning & 3.34 & 5.30 & 3.71 & 5.26 & 3.67 & 5.57 & 4.07 & 5.53 & 4.32 \\
\hline Temporary integration in eco-farms & 3.20 & 5.30 & 3.82 & 5.26 & 4.33 & 5.71 & 4.21 & 5.53 & 4.50 \\
\hline Health and wellness & 4.89 & 5.30 & 5.21 & 5.26 & 4.00 & 5.86 & 5.00 & 5.53 & 5.04 \\
\hline Gastronomy and wines & 4.72 & 5.30 & 4.98 & 5.26 & 5.00 & 5.71 & 5.73 & 5.53 & 5.26 \\
\hline Touring architectural and archaeological & 4.40 & 5.30 & 4.46 & 5.26 & 5.00 & 5.86 & 5.67 & 5.53 & 5.16 \\
\hline Landscape touring and picnics & 4.63 & 5.30 & 4.50 & 5.26 & 4.67 & 5.71 & 5.27 & 5.53 & 5.04 \\
\hline Outdoor fairs and markets & 4.61 & 5.30 & 4.81 & 5.26 & 4.00 & 5.00 & 5.00 & 5.53 & 4.77 \\
\hline Outdoor shows and performances & 4.63 & 5.30 & 5.18 & 5.26 & 4.00 & 5.29 & 5.13 & 5.53 & 4.90 \\
\hline Outdoor religious processions & 2.54 & 5.30 & 3.78 & 5.26 & 3.33 & 5.14 & 4.13 & 5.53 & 4.07 \\
\hline
\end{tabular}

A: $15 \%$ * Mean of tourists' preference for each recreation activity $(\mathrm{N}=400)$; $\mathrm{B}: 5 \%$ * Mean of tourists' preference for each landscape unit $(\mathrm{N}=400) ; \mathrm{C}: 15 \%{ }^{*}$ Mean of residents' preference for each recreation activity $(\mathrm{N}=400)$; D: $5 \%{ }^{*}$ Mean of residents' preference for each landscape unit ( $\left.\mathrm{N}=400\right)$; E: $20 \%{ }^{*}$ Mean of enhancement potential considered by experts for each recreation activity and landscape unit (N=3); F: 20\%* Mean of enhancement potential considered by stakeholders for each recreation activity and landscape unit (N = 7); G: $15 \%$ * Mean of enhancement potential considered by tour operators for each recreation activity $(\mathrm{N}=15) ; \mathrm{H}: 5 \%$ * Mean of enhancement potential considered by tour operators for each landscape unit $(\mathrm{N}=15)$.

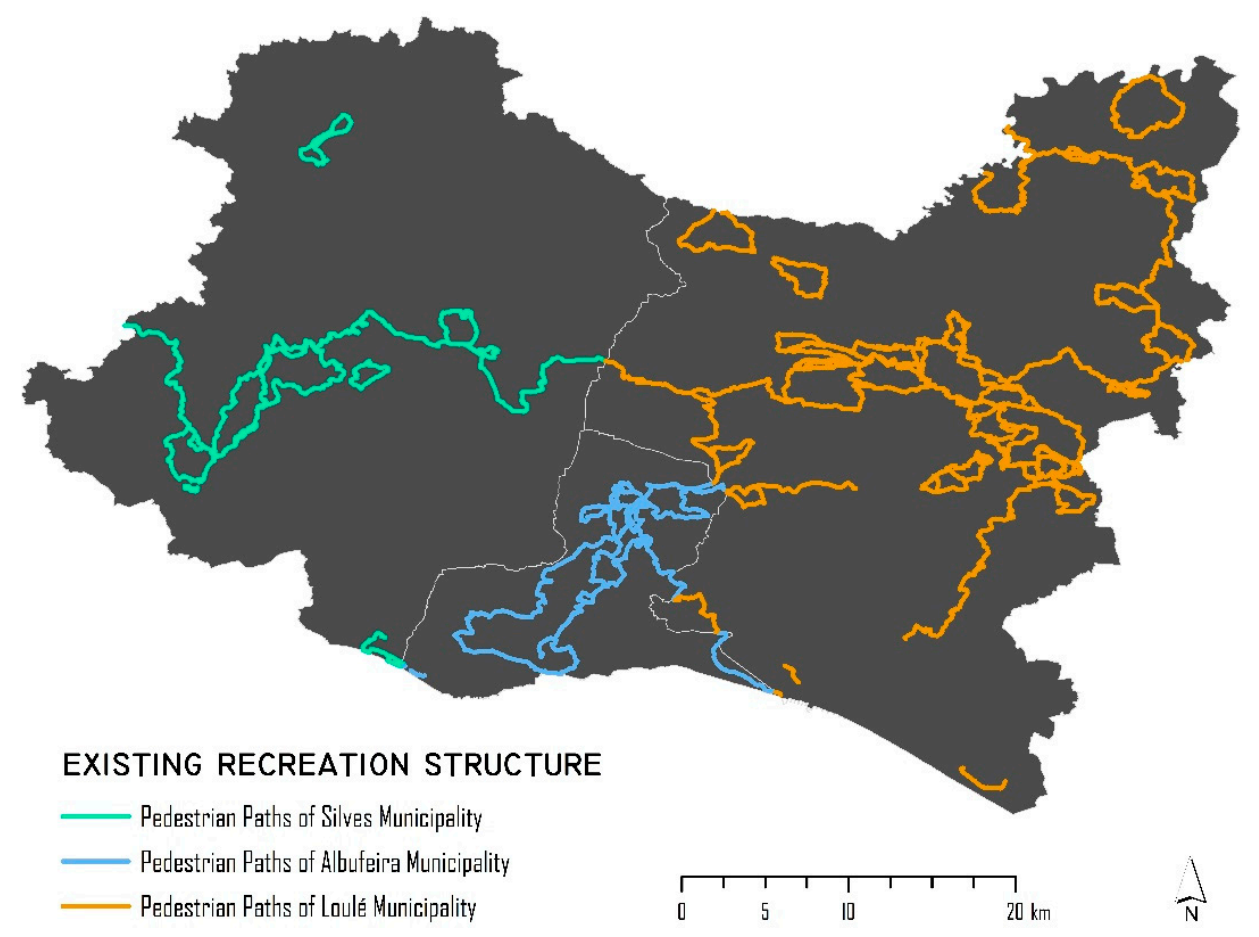

Figure 2. Trails and boardwalks of Silves, Albufeira, and Loule municipalities in the Algarve region of Southern Portugal. 
In addition to the existing recreation structure, there are spheres in the study area that can still be incremented and interconnected, namely those that do not have paths, trails, or recreational spaces. However, this strategy must respect the landscape's ecological sensitivity in order to represent a strategy for territorial cohesion and sustainable tourism development.

In this context, a suitability map (Figure 3 with the example for walks, orienteering, and keep-fit circuits), grounded on a score scale from 0 -No suitability to 1-High suitability, was created to help the public and private sectors in defining strategies to increment the recreation structure for each nature-based and cultural activity, studied through the surveys, based on the multicriteria evaluation of the factors listed in Table 4 (for the same example).

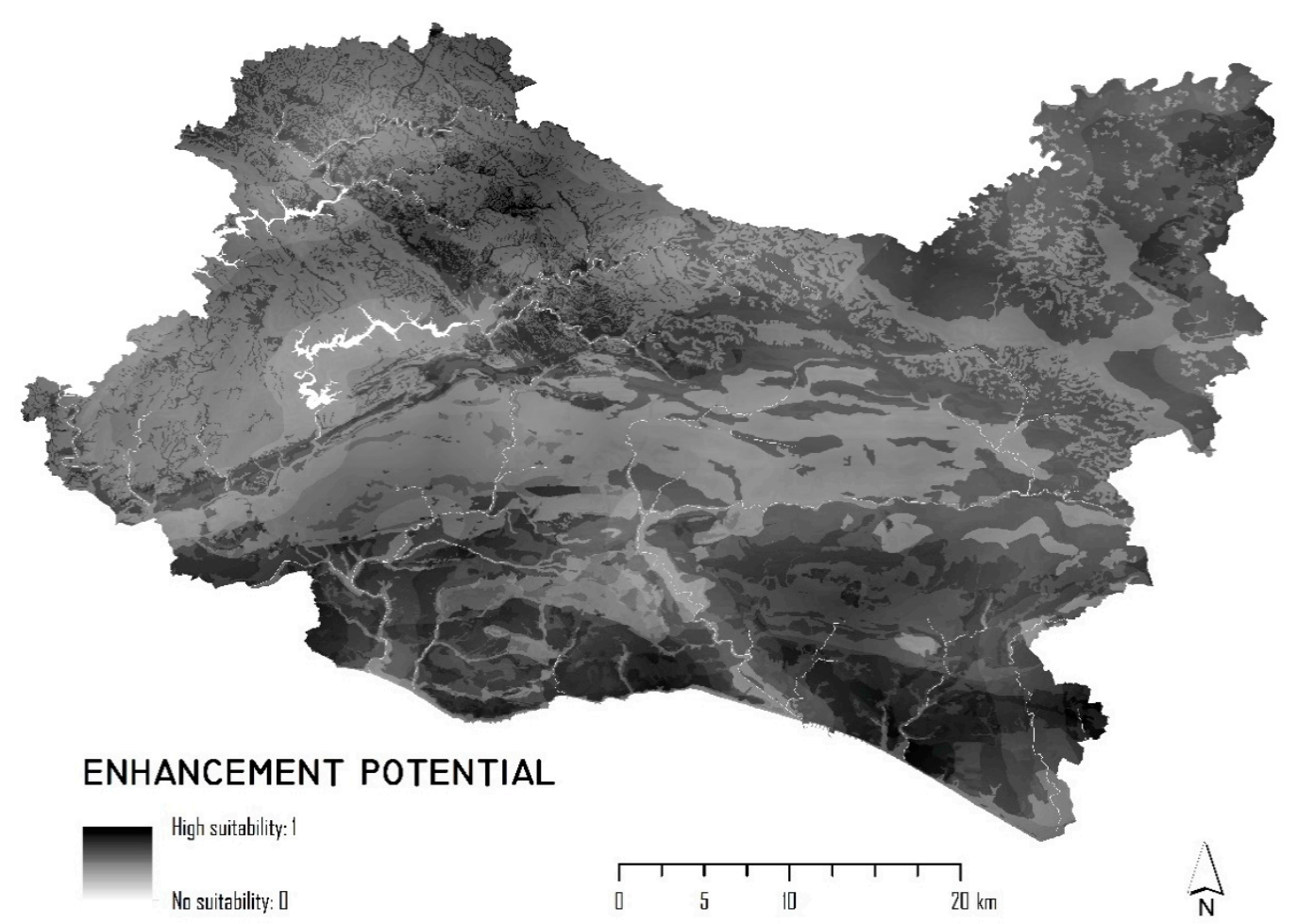

Figure 3. Suitability map of enhancement potential for the creation of new pedestrian paths of Silves, Albufeira, and Loulé municipalities, Algarve region, southern Portugal. 
Table 4. Multicriteria evaluation factors, respective fuzzy functions and factor weight.

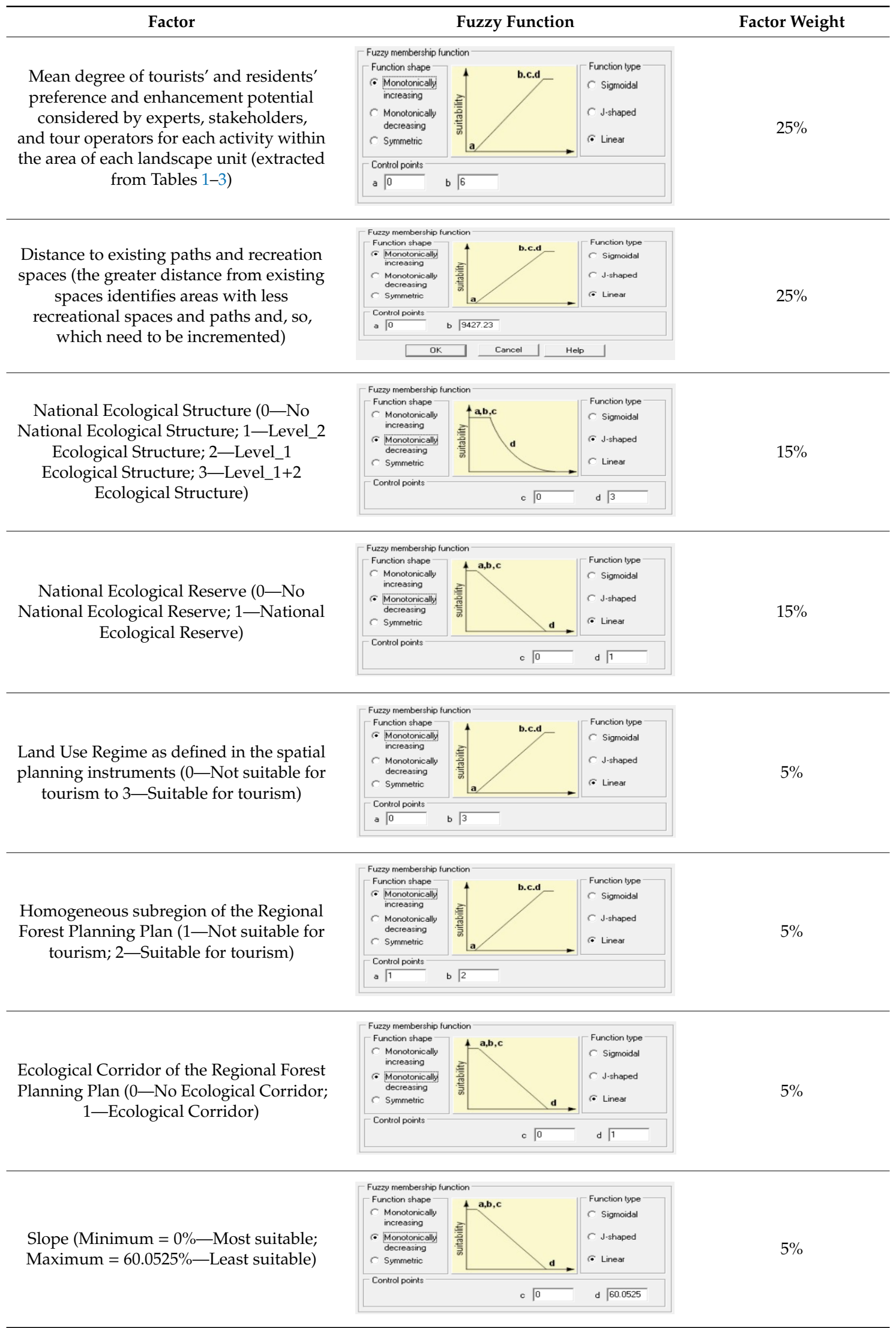




\section{Conclusions}

The present study highlights the activities that should be promoted, besides the sun-and-sea product. It makes it possible to analyze the structure of existing paths, trails, and recreational spaces for each of the activities studied in the surveys applied to tourists, residents, experts, stakeholders, and tour operators, and to identify areas that do not have recreational facilities, so as to be scaled up and interconnected with existing ones.

This research identifies the high potential for enhancement of the most preferred and considered of the alternative recreational activities, differentiated by each landscape unit, namely walks, orienteering, and keep-fit circuits, health and wellness, rural accommodation, gastronomy and wines and landscape touring and picnics for the Algarve Interior Mountains landscape; rural accommodation, walks, orienteering, and keep-fit circuits, gastronomy and wines, touring architectural and archaeological sites, health and wellness, and landscape touring and picnics for the Barrocal Midlands landscape; and walks, orienteering, and keep-fit circuits, health and wellness, gastronomy and wines, outdoor shows and performances, and touring architectural and archaeological sites for the Coastal landscape.

This territorial model should serve as the basis for a strategy of diversifying tourism products with a view for strengthening the regional resilience, where digital marketing, supported by the need for creation of geolocation apps, can be the main method of promotion [41]. The survey study identified the activities that can be enhanced and promoted in addition to the sun-and-sea product, in order to guide a management strategy and promotion of this destination, based not only on the enhancement potential considered by experts, stakeholders, and tour operators, but also in the diversification of products that are differentiated by the corresponding adherence to preferences of tourists and residents. Tourism diversification and differentiation should come from the sustainable management of these municipal territories and their tourism assets, providing advantages in presenting a rejuvenated and long-term viable destination, ensuring its sustainability [42].

The limitations of the study, which constitute important opportunities for future research, correspond to the need to study a governance structure that encourages synergies between resident communities, landowners, and tour operators, which may enable this diversification transition. Measuring the environmental and socioeconomic impact of this proposed recreational enhancement is paramount as an ongoing research need, since monitorization is imperious to the proposal implementation in order to avoid environmental degradation, gentrification, and tourism massification in today's low-density territories of the Algarve's interior mountains and Barrocal midlands, which still preserve more of their landscapes' ecological sensitivity compared to the coastal unit.

Author Contributions: Conceptualization, A.S.-A., J.F., E.V., and T.P.; methodology, A.S.-A. and J.F.; formal analysis, A.S.-A.; investigation, A.S.-A.; writing-Original draft preparation, A.S.-A. and T.P.; writing-Review and editing, T.P.; supervision, E.V., T.P. and J.F. All authors have read and agreed to the published version of the manuscript.

Funding: This research was funded by the Foundation for Science and Technology (FCT), grant number PTDC/GES-URB/31928/2017 and Interreg Atlantic Area project TrailGazerBid: "An analytical \& technical framework to measure returns from trail investment."

Acknowledgments: The first author would like to thank dearly the expert's participation, here enunciated by alphabetic order: Professor Ana Paula Barreira, Professor Pedro Prista and Professor Rosário Oliveira. In the same way, the authors thank the stakeholders' and tour operators' participation, as well as the participation of all anonymous tourists and residents who were willing to contribute to this study. This paper was financed by the FCT- Fundação para a Ciência e Tecnologia through the PhD grant SFRH/BD/102328/2014.

Conflicts of Interest: The authors declare no conflict of interest. 


\section{References}

1. Romão, J.; Neuts, B. Territorial Capital, Smart Tourism Specialization and Sustainable Regional Development: Experiences from Europe. Habitat Int. 2017, 68, 64-74.

2. Samora-Arvela, A.; Ferreira, J.; Panagopoulos, T.; Vaz, E. Tourists, Residents and Experts Rethink the Future of Mediterranean Regions: Can Tourism Diversification Contribute to Climate Change Adaptation? The Case of the Algarve Region, Southern Portugal. In Regional Intelligence: Spatial Analysis and Anthropogenic Regional Challenges in the Digital Age; Vaz, E., Ed.; Springer: Cham, Switzerland, 2020.

3. Romão, J. Turismo e Lugar-Diferenciação Territorial, Competitividade e Sustentabilidade em Turismo; Escolar Editora: Lisbon, Portugal, 2013.

4. Panagopoulos, T.; Antunes, M.D.C.; Karanikola, P.; Lakoova, L. Rural Renaissance through Synergies of Land and Sea Communities. In Proceedings of the 6th International Conference on Environmental Management, Engineering, Planning \& Economics, Thessaloniki, Greece, 25-30 June 2017; pp. 1217-1222.

5. Butler, R. The Concept of a Tourism Area Life Cycle of Evolution: Implications for Management of Resources. Can. Geogr. 1980, 24, 5-12. [CrossRef]

6. Plog, S. Why Destination Areas Rise and Fall in Popularity. Hotel. Restaur. Adm. Q. 1972, 14, 55-58. [CrossRef]

7. Cohen, E. Towards a Sociology of International Tourism. Soc. Res. 1972, 39, 164-182.

8. Butler, R. Tourism in the Future: Cycles, Waves and Wheels? Futures 2008, 41, 346-352. [CrossRef]

9. Russo, P. The Vicious Circle of Tourism Development in Heritage Cities. Ann. Tour. Res. 2002, $29,165-182$. [CrossRef]

10. Agarwal, S. Coastal Resort Restructuring and the TALC. In The Tourism Area Life Cycle: Conceptual Theoretical Issues; Butler, R.W., Ed.; Channelview Publications: Clevedon, UK, 2006; pp. 201-218.

11. Baum, T. Revisiting the TALC: Is there an Off-Ramp? In The Tourism Area Life Cycle: Conceptual and Theoretical Issues; Butler, R.W., Ed.; Channelview Publications: Clevedon, UK, 2006; pp. 219-230.

12. Lagiewski, R.M. The application of the TALC: A literature Survey. In The Tourism Area Life Cycle: Conceptual and Theoretical Issues; Butler, R.W., Ed.; Channelview Publications: Clevedon, UK, 2002; pp. 27-50.

13. Benur, A.; Bramwell, B. Tourism Product Development and Product Diversification in Destinations. Tour. Manag. 2015, 50, 213-224. [CrossRef]

14. Samora-Arvela, A.; Vaz, E.; Ferrão, J.; Ferreira, J.; Panagopoulos, T. Diversifying Mediterranean Tourism as a Strategy for Regional Resilience Enhancement. In Resilience and Regional Dynamics; Pinto, H., Noronha, T., Vaz, E., Eds.; Springer: Cham, Switzerland, 2018; pp. 105-127. [CrossRef]

15. Weaver, D. Sustainable Tourism-Theory and Practice; Elsevier: Oxford, UK, 2006.

16. Budowski, G. Tourism and Environmental Conservation: Conflict, Coexistence, or Symbiosis? Environ. Conserv. 1976, 3, 27-31. [CrossRef]

17. Buhalis, D. Marketing the Competitive Destination of the Future. Tour. Manag. 2000, 21, 97-116. [CrossRef]

18. Porter, M. Industry Scenarios under Competitive Strategy under Uncertainty. In Competitive Advantage-Creating and Sustaining Superior Performance; The Free Press: New York, NY, USA, 1985; pp. 445-481.

19. Hassan, S. Determinants of Market Competitiveness in an Environmentally Sustainable Tourism Industry. J. Travel Res. 2000, 38, 239-245. [CrossRef]

20. Hall, C.M.; Williams, A.M. Tourism and Innovation; Routledge: London, UK, 2008.

21. Hjalager, A. A Review of Innovation Research in Tourism. Tour. Manag. 2010, 31, 1-12. [CrossRef]

22. Boes, K.; Buhalis, D.; Inversini, A. Smart Tourism Destinations: Ecosystems for Tourism Destination Competitiveness. Int. J. Tour. Cities 2016, 2, 108-124. [CrossRef]

23. Karanikola, P.; Panagopoulos, T.; Tampakis, S.; Tsantopoulos, G. Cycling as a Smart and Green Mode of Transport in Small Touristic Cities. Sustainability 2018, 10, 268. [CrossRef]

24. Caragliu, A.; Del Bo, C.; Nijkamp, P. Smart Cities in Europe. J. Urban Technol. 2011, 18, 65-82. [CrossRef]

25. Binkhorst, E.; Den Dekker, T. Agenda for Co-Creation Tourism Experience Research. J. Hosp. Mark. Manag. 2009, 18, 311-327. [CrossRef]

26. Kim, J.; Fesenmaier, D.R. Measuring Emotions in Real Time: Implications, for Tourism Experience Design. J. Travel Res. 2015, 54, 419-429. [CrossRef]

27. Palos-Sanchez, P.; Saura, J.R.; Reyes-Menendez, A.; Esquivel, I.V. Users Acceptance of Location-Based Marketing Apps in Tourism Sector: An Exploratory Analysis. J. Spat. Organ. Dyn. 2018, 6, 258-270. 
28. Lu, J.; Mao, Z.; Wang, M.; Hu, L. Goodbye Maps, Hello Apps? Exploring the Influential Determinants of Travel App Adoption. Curr. Issues Tour. 2015, 18, 1059-1079. [CrossRef]

29. Cancela d'Abreu, A.; Pinto Correia, T.; Oliveira, R. Contributos para a Identificação e Caracterização da Paisagem em Portugal Continental; Direcção-Geral do Ordenamento do Território e Desenvolvimento Urbano: Lisbon, Portugal, 2004; Volume V, pp. 171-218.

30. Brito, S.P. Território e Turismo no Algarve; Edições Colibri: Faro, Portugal, 2009.

31. Santos, F.S. Intervir na Paisagem; Argumentum: Lisbon, Portugal, 2017.

32. Panagopoulos, T.; Karanikola, P.; Tampakis, S.; Gounari, N.; Tampakis, A. Rural Renaissance-Fostering Innovation and Business Opportunities in the Quarry Sector of Paggaio Municipality. In Proceedings of the 8th International Conference on Information and Communication Technologies in Agriculture, Food and Environment, Chania, Greece, 21-24 September 2017; pp. 415-421.

33. Silva, J.A.; Mendes, J.; Valle, P.; Guerreiro, M. Consumos culturais dos turistas do Algarve; Direcção Regional da Cultura do Algarve: Faro, Portugal, 2007.

34. Valle, P.; Guerreiro, M.; Mendes, J.; Silva, J.A. The Cultural Offer as a Tourist Product in Coastal Destinations: The Case of Algarve, Portugal. Tour. Hosp. Res. 2011, 11, 233-247. [CrossRef]

35. Mendes, J.; Henriques, C.; Guerreiro, M. Dos recursos às temáticas culturais na gestão do turismo cultural no Algarve. Int. J. Sci. Manag. Tour. 2015, 4, 31-48.

36. Samora-Arvela, A.; Vaz, E.; Ferreira, J.; Panagopoulos, P. Turismo e Património Gastronómico: A valorização turística de um cabaz de doçaria algarvia. Public Policy Port. J. 2017, 2, 55-69.

37. INE, Inquérito à Permanência de Hóspedes na Hotelaria e Outros Alojamentos em 2015; Instituto Nacional de Estatística: Lisbon, Portugal, 2016.

38. INE, Censos 2011-Resultados Definitivos; Instituto Nacional de Estatística: Lisbon, Portugal, 2013.

39. Jiang, H.; Eastman, J.R. Application of Fuzzy Measures in Multi-Criteria Evaluation in GIS. Int. J. Geogr. Inf. Sci. 2000, 14, 173-184. [CrossRef]

40. Eastman, J.R. TerrSet Geospatial Monitoring and Modeling System; Clark University: Worcester, MA, USA, 2016; pp. 345-389.

41. Simões, J.M.; Ferreira, C.C. The Tourism-Territory Nexus: Challenges for Planning. In Proceedings of the International Conference Sustainable Tourism: Issues, Debates \& Challenges, Crete \& Santorini, Greece, 22-25 April 2010; Wickens, E., Soteriades, M., Eds.; pp. 1060-1068.

42. Ritchie, J.; Crouch, G. The Competitive Destination: A Sustainable Tourism Perspective; CABI International Publishing: Wallinford, UK, 2003. 